\title{
Housing Policy in Ghana: The Feasible Paths
}

\author{
Nicholas A. Boamah \\ Department of Real Estate and Land Management \\ University for Development Studies, Wa Campus, Ghana \\ Email:addaianas@yahoo.com \\ DOI: http://dx.doi.org/10.4314/gjds.v11i1.1
}

\begin{abstract}
Several housing policies have been implemented in Ghana since independence in 1957. Despite these policies, housing in Ghana is characterized by inadequate housing stock, overcrowding, congestion, housing decay, and neighbourhood blight. The paper examines the outcomes of pre and post-colonial housing policies in Ghana. It determines the feasible way forward for the country's housing policy. This is done through literature, documentary and archival surveys. It notes that past housing policy interventions in Ghana failed to realize their intended objectives. The paper suggests that housing policies in the country should focus on developing the housing finance market; establishing community based housing finance schemes; enforcement of planning controls; and confining government's role to regulating the housing market rather than assuming housing developer and financier responsibilities.
\end{abstract}

Keywords: Housing Policy, Housing Finance, Planning Controls, Housing Research, Ghana

\section{Introduction}

The development of a nation partly hinges on the availability of an efficient housing sector which is capable of delivering adequate housing to meet the housing needs of its citizens. Housing sufficiency is necessary in providing shelter and ensuring the wellbeing of people; ensuring efficient resource allocation in an economy; and impacts on economic growth and social stability in every nation (Boamah, 2011). Housing impacts significantly on households' health and income. Homelessness and housing inadequacy correlate with HIV risk and infection rates (Corneil, Kuyper, Shoveller Hogg, Li, Spittal \& Wood, 2006; Surratt \& Inciardi, 2004). Housing inadequacies lead to stress amongst households, poor performance of school children and child health problems (Conger, Patterson \& Ge, 1995; Krieger \& Higgins, 2002). A vibrant housing sector is therefore a pre-requisite for an accelerated development of nations. A dynamic housing sector is vital to the better functioning of the labour mobility mechanisms and job creation programmes; labour is employed directly in the construction of houses and related infrastructure (Sandilands, 2002). 
The benefits of housing cannot be realized without the formulation and implementation of efficient and dynamic housing policy. Housing policies are germane for the realization of the economic policy objectives of nations such as investment drive, wealth creation, skills development and job creation ( $\mathrm{CMHC}$, 2004). A nation's housing policy must therefore comprehensively address the housing needs of its citizens; it must ensure the provision of adequate housing, development of an efficient and sustainable means of housing finance, promote sustained housing research, be responsive to changing housing needs of the citizens and ensure planned and orderly development. Therefore, to be successful the policy must reflect both the past and the future. Thus, Thorns (2006) notes that housing policy shifts are embedded in the past as well as in the future. Parson (1995) argues that the prevailing policies set the agenda for new challenges and provide the framework for constructing problems. It is therefore important for policy makers to have an appreciation of the past as well as the future if they are to formulate and implement workable housing policies. Policy makers need to understand the past and future population dynamics, tenurial system, the composition of households and the nature of the country's housing stock. The housing policy must look at the past, the short term, and the long term; housing must be considered in both the short and long-term planning of a country.

The various governments of Ghana since independence recognized the important role of housing and the necessity of an efficient housing policy if the nation was to realize its full benefits. Post-independence governments of Ghana implemented various policies with the aim of facilitating the development of the housing sector. These policies focused basically on housing subsidies, public sector housing delivery; private sector led housing market; the establishment of housing finance institutions; rent controls; slum upgrading programmes; site and service schemes; and cooperative housing schemes. Despite the formulation and implementation of several housing policies, the country's housing sector remains underdeveloped. Housing inadequacy, decay, and haphazard development is a feature of the country's housing sector. In 2010, 54.4 percent, 24.3 percent and 21.3 percent of households respectively occupied one, two and at least three sleeping rooms with an average household size of 4.4 persons (Ghana Statistical Service, 2013). The data imply that about $78.7 \%$ of households in the country had inadequate sleeping rooms; more than two persons occupied one sleeping room. The state of housing in the country is appalling, it is a signal that the country's housing policies have failed to achieve their intended objectives of providing adequate and affordable housing to Ghanaians.

The paper reviews the housing policies in Ghana since the colonial era. It examines the outcome (quantity, quality and adequacy of housing) of the various housing policies and explores the best way forward for housing policy in Ghana. It obtained secondary data from the existing literature and official sources such as the Housing Finance Company (HFC), Ghana Statistical Service, the Ministry of Works and Housing (MWH), and from the housing policies of Ghana. It gathered information via official documentary surveys. 


\section{Public and Private Sector Centred Housing Policy}

National housing policies may focus on market-led housing delivery or State sponsored housing programmes or both. Public housing may have an embedded subsidy for the lowincome households. Public housing projects may also enhance the quality of the housing stock and the living environment (Katz, Kling \& Liebman, 2001). An efficient public housing provision will increase the housing stock and not crowd-out privately provided housing. Sinai and Waldfogel (2005) note that an essential requirement for public housing provision is that it has a real effect on recipients' outcomes. Sinai and Waldfogel (2005) argue that if the publicly supplied housing is allocated to households with no private demand, then the public units would increase the housing stock and no crowd out would occur. If the public units are, however, allocated to a household purchasing private housing, then the program would reduce demand for private housing. Public housing would therefore not raise the number of units in the housing stock, and would not increase housing consumption by the poor.

Households requiring public housing may not necessarily be able to access it. This may partly be due to complicated eligibility criteria and corruption in the administration of the programme. Otiso (2003) argues that States are unable to provide adequate housing as a result of administrative, financial, and institutional weaknesses; poor planning mechanisms; and rapid population growth.

Public housing schemes impose huge financial burden on governments and are thus unsustainable. It is thus not surprising that State agencies contribution to the total housing output tends to be minimal in most developing countries. Public housing initiatives are associated with large-scale resource misallocation arising from corruption, nepotism, or rent-seeking behaviour of public officials (Vakil, 1999). The design of public housing generally ignores the needs of the intended beneficiaries and thus may make limited impact on their housing experience. State sponsored housing projects may thus not achieve their intended purposes.

Early (1998) argues that public housing programmes that fail to deliver housing to those mostly at risk of homelessness will not improve the housing conditions. For instance, corruption in the allocation of housing units contributed to the failure of public housing projects in Ghana (Konadu-Agyemang, 2001). State housing provision may be proned to political manipulations leading to frequent overhauls, uncertainty, and disruption of such programmes (Mahama \& Antwi, 2006). Direct housing delivery by the State may be inefficient, ineffective, and expensive venture with limited outcomes. Sengupta (2006) suggests that government housing provision resulted in sub-optimal housing investment and undermined the ability of the market to increase housing supply in Kolkata. Most of the publicly provided affordable housing units are not affordable by the majority of the low-income earners. The institutional setting for delivering public housing is generally ineffective. Public housing approaches have been unsuccessful in meeting the housing needs of households most in need of housing (Ogu \& Ogbuozobe, 2001). They note that 
public housing schemes in Nigeria made little impact on the housing consumption by the low-income households.

Private sector led housing delivery may help in addressing the inherent problems in State sponsored housing programmes. Market based interventions may be more successful in providing housing even for the low-income households (Dowall, 1989). The private sector has the capacity - production efficiency, technical and marketing expertise and financial capability to supply housing to households. This however, hinges on the existence of profit making opportunities. Private sector actors may abandon housing delivery for poor households particularly the most vulnerable (Jones and Ward, 1995; Sanyal, 1996). Low-income households may suffer from housing inadequacy partly because the market would deliver limited affordable housing units (Olsen 2001). Due to limited profit-making opportunities, the private sector is generally disinterested in the provision of housing and urban services to low-income communities (Vakil, 1999).

Private sector housing initiatives were unsuccessful in providing housing for the poor in Philippine (Strassman, 1994). Bond and Tait (1997) suggest that the private sector focused housing policy failed to increase low-income housing delivery in South Africa. They argue that the private sector may focus on delivering housing to households where the riskreward relationship may be more favorable. This may not favor low and middle income families. Low and middle-income households may be priced out of the housing market in the absence of government interventions in an era of a market-led housing policy. The private sector may not deliver low-income housing; however, planning regulations could be relied on to compel the private sector to provide affordable housing. The private sector would thus deliver housing down the market (through mix development) if adequate government regulation exists. An efficient land use planning regime is an important tool in this regard.

\section{A Review of Housing Policies in Ghana}

The Ghana government's involvement in housing provision has been done through various policy interventions. Several housing policies and programmes have been implemented in Ghana since the colonial era. The political ideology of the implementing government however, determined the focus of the various policies. As a result, the Ghanaian housing policy has not been consistent.

During the colonial era, the focus was not to cater for the housing needs of the entire population. The colonial government's sole interest was the provision of housing for its expatriate staff and the senior indigenous staff in the colonial public service (Abiodun, 1976, Hornsby-Odoi \& Akpey, 1988). Konadu-Agyemang (2001) argues that there was a limited welfare State and the State focused on housing delivery only for its own officers and the expatriate staff of European companies. Similarly, the colonial government leased serviced building plots but only to the affluent members of society. Mahama and Antwi (2006) suggest that one's ability to construct an expensive European style 
house determined his access to serviced building lots. The free market system regulated the provision and the acquisition of land for low income housing (Songsore, 2003). The colonial government enacted town and country planning laws which hindered the ability of the natives to acquire housing especially in the urban centers of the country (KonaduAgyeman, 2001). The colonial town and country planning laws ignored the socio-economic state of the indigenous people and made it almost impossible for them to acquire building sites particularly in the urban centres.

Serious State efforts at delivering housing to the majority of Ghanaians only started after the country's independence in 1957. The housing policy emphasized the provision of public sector housing over the 1957 to 1966 period. The State embarked on mass public housing programmes and provided subsidy packages in the form of roof loans scheme, self-help housing scheme, and the provision of serviced sites. The Tema Development Corporation (TDC) and the State Housing Corporation (now known as State Housing Company) respectively delivered 10,700 and 1,052 low-cost housing units under this policy. This housing policy was however, abandoned after the violent overthrow of the government in 1966. From 1969 to 1971 the policy focus changed; public sector housing delivery was de-emphasized and private sector participation in the housing sector encouraged. The policy led to the extraction of all rental subsidies and increased rent on all State housing units to economic levels. The defunct Bank for Housing and Construction (BHC) was also established to offer concessionary construction finance and mortgages respectively to housing developers and home buyers. A supply side subsidy was thus offered through the BHC. The BHC granted a total of 363 mortgages between 1974 and 1988 (Konadu-Agyemang, 2001). The mortgage investment by the BHC over this fourteen year period was minimal and insignificantly impacted on housing development in the country (Boamah, 2009). Fraudulent deals however, wiped out the entire capital of the BHC leading to its collapse in 2000. The implementing government was overthrown in a coup d'etat in 1972.

Between 1972 and 1979 the housing policy of the previous administration (1969 to 1972) was suspended and subsidies re-introduced. The implementation of this policy led to an increase in public sector housing investment with the TDC for instance delivering 7,380 subsidized housing units. It focused on reducing infrastructure and building construction costs; the provision of low-income housing nationwide; the development and use of local building materials; and housing standards improvement. The Supreme Military Council Decree 23 (SMCD 23) was promulgated to initiate a national mortgage guarantee scheme in the country. The intended development of the housing finance market could not be realized due to the economic instability in the country over the period.

From 1982 to 1989, funding and infrastructure grant to the State housing institutions were withdrawn and rent controls on both public and private sector housing implemented. The same regime also liberalized the housing sector in 1988 and established the Home Finance Company (HFC) in 1991. The onus of housing delivery was therefore vested in the private sector. Unfortunately, the real estate firms failed to deliver low-cost or rental 
housing units. It would be naive for the government to think that these firms would produce low-cost housing for the urban poor given their profit maximization objective (Konadu-Agyemang, 2001). Leaving housing delivery entirely in the hands of profit maximizing firms without some form of State intervention (for instance via the land use planning system) further perpetuated the prevailing housing inequality in terms of quality and quantity in the country. Planning regulations should be employed to ensure that developers pursue mix development and accommodate affordable housing in their development schemes. This is necessary in minimizing income driven social segregation in the country's residential neighborhoods.

Between 1992 and 2013, there has been little State involvement in the housing sector. The Social Security and National Insurance Trust (SSNIT) owns some rental units in the regional capitals of the country. About 3,000 acres of land were acquired in 2001 at Accra, Brekuso, Kuntanase, Asokore-Mampong, Wa and Amanfrom for the provision of affordable housing units. Like previous interventions, these projects have been abandoned by the succeeding governments. It appears that the political actors have failed to realize the huge financial waste in the public housing delivery system as a result of project abandonment or have not learnt a lesson from the disregard of previous housing interventions or neglect the housing projects of the previous government for political expediency. The ease with which succeeding governments set-aside the housing projects of prior governments is a major constraint on public sector housing delivery in Ghana. The financial waste caused by the neglect of ongoing housing projects has an economywide effect. The disregard of public housing projects holds up public funds in uncompleted buildings, creates environmental nuisance, provides a place of abode for miscreants, and leads to the delivery of aesthetically and functionally obsolete properties on completion.

\section{Outcomes of Past Housing Policy Interventions in Ghana}

Housing provision by the post-independence governments of Ghana through the several housing policies and strategies has had insignificant impact on housing delivery, affordability and access by the poor and low income households in the country. The policy interventions have been unable to deliver adequate and affordable housing to Ghanaians. The State housing institutions have not been effective conduits for housing development in the country. The SHC was only able to deliver 38 percent and 13 percent of its targeted output under the 1959-64 and 1967-69 housing policies respectively (Tipple, 1987). Also, the TDC was in arrears of over 20,000 housing units by 2000 . The SHC delivered a total of about 20,773 housing units, 8,417 of which are in Accra since its inception in 1955 (Karley, 2008). The SHC therefore delivered on average 415 housing units per annum for its over 50 years of operation. The housing corporations and agencies received more than a proportionate amount of the housing budget but despite these huge investments they consistently failed to meet their targets and delivered less than six percent of the national housing need (Konadu-Agyeman, 2001). 
The bulk of the housing stock in Ghana is delivered by the undercapitalized individual households through the "Do-it-Yourself" (DIY) financing process. The DIY financing medium delivers housing incrementally. Housing supply is mostly done by households rather than real estate developers or government (Bank of Ghana [BoG], 2007). The bulk of affordable housing supply in Ghana is through informal ways of incrementally developing and building housing ( $\mathrm{CHF}, 2004)$. The informal sector delivers 30,000 housing units annually whilst the formal sector produces only 2,500 units at its peak (Akuffo, 2006). It is the little efforts of individual small scale housing financiers that drive housing development in the country (Konadu-Agyemang, 2001). The Government policy interventions botched in reaching the low income target groups or in meeting their housing requirements. As pointed out by Stren (1990), the State sponsored housing programmes are notoriously proned to leakage; the rich and the powerful rely on their influence and positions and take control of housing units meant for the poor. Most of the low income households end up as tenants in the housing units that were earmarked for them due to corruption in the allocation of the public housing units.

Despite the implementation of several housing policies and programmes in the country, increases in housing stock have lagged behind population growth and there is degradation of the existing housing stock. About two percent of the Ghanaian population relies on shift dwelling units such as kiosks, tents, cargo containers, and attachment to shops for shelter (GSS, 2002). Overcrowding, decaying properties, haphazard development, poor drainage, poorly designed structures, declining quality and inadequate access to services characterize much of the housing stock in the country; BoG, 2007; Karley, 2008; Obeng-Odoom \& Amedzro, 2011). The problem confronts almost all the cities and towns in Ghana. For instance, Oppong and Adarkwa (2008) observe that the housing units in Abakam in the Central Region Ghana are structurally unstable. Kofie and Nabila (2004) and Adjei and Kyei (2013) associate the high disease prevalence in rural Ghana to structurally defective housing and inadequate sanitation and drainage facilities. Boamah (2012) observes deteriorating housing in the Offinso South Municipality and associates it with the poor performance of school children in the municipality.

\section{The Feasible Paths for Housing Policy in Ghana}

The magnitude of the housing problem in Ghana is huge. The housing problems in the country are characterised by both a backlog in the provision of formal housing and the resultant sprawl of informal settlements (Karley, 2008). Ghana must therefore, create the appropriate environment necessary for the development of the housing sector and consequently enable the sector to contribute meaningfully to the socio-economic development of the nation. A clearly defined and result-oriented housing policy is required if Ghana is to attain an accelerated development of the country's housing sector and deliver housing on sustained basis to Ghanaian households. The formulation and implementation of housing policies must be made a national priority; there must be political commitment to the development of the sector. 
The housing policy must create room for both the public and private sectors of the Ghanaian economy to contribute to housing provision. It must focus government interventions on the creation of enabling environment and regulation of the housing sector whilst allowing the private sector to lead the financing and development of housing in Ghana. The State must exercise its supervisory responsibility over the housing sector but State regulation should not be likened to State control. The State must not monopolize housing delivery nor seek to control the private sector in the delivery and financing of housing. The housing policy must create affordable, efficient and sustainable housing finance regime; adequately deal with the poor conditions and decrepitude of the existing housing stock; improve the housing environment; strengthen planning controls and enforcement; and focus on sustained housing research to be successful. The proposed housing policy menu is shown in figure 1.

Figure 1: Housing Policy Menu

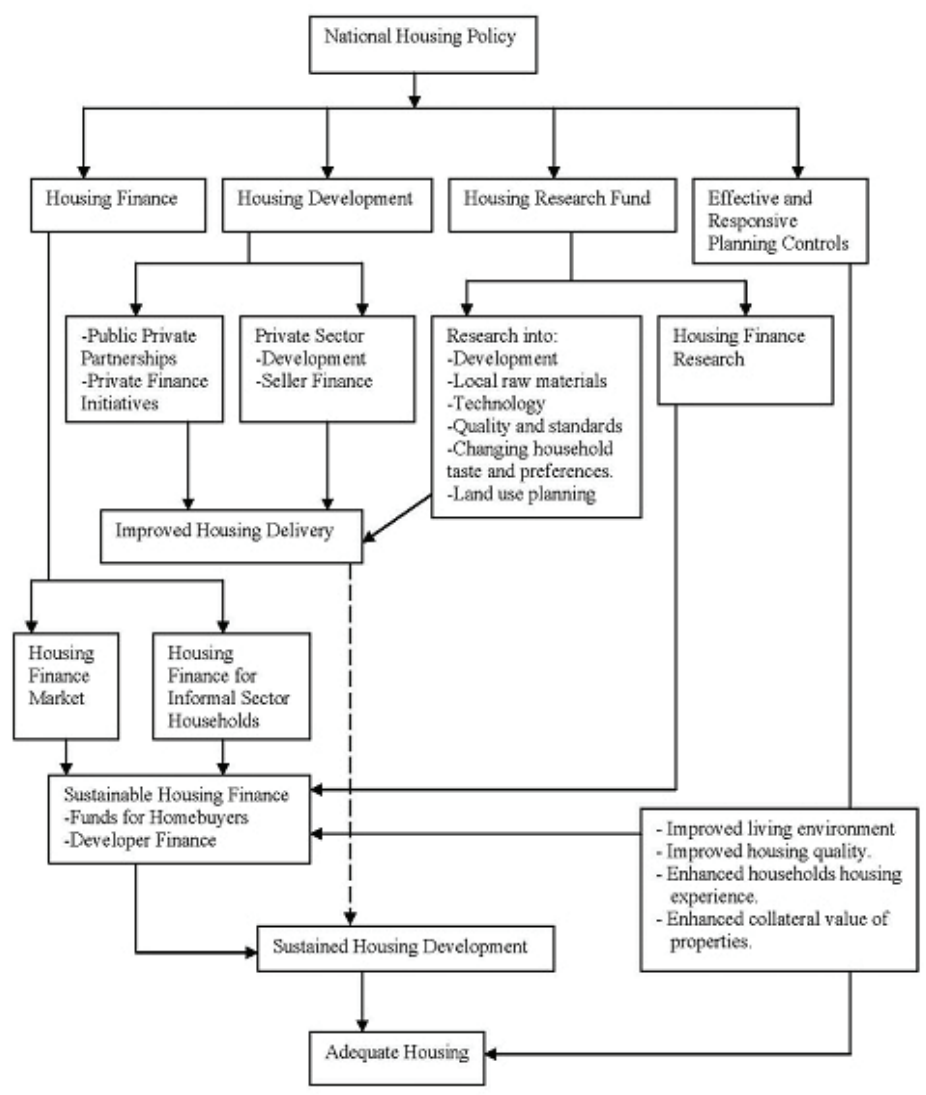

Source: Author's Construct, 2013 


\section{Development of Housing Finance Market}

Access to affordable and sustainable housing funds is extremely essential for the provision of adequate shelter for the citizens of a country. Buckley (1996) observes that in the developing world, housing finance is in extremely short supply. As has been noted earlier, housing finance is mostly done through informal processes in Ghana. Housing supply in Ghana will continuously lag behind demand so long as housing financing and development is largely done through informal processes. Ghana will not be able to provide adequate housing if the housing finance market remain underdeveloped. Availability of funds is a major challenge to affordable housing delivery in Ghana. The lack of formal housing finance market has retarded housing development in the country considerably, as home builders have had to invest gradually out of their income. Hettne (1990) observes that the State cannot meet the housing demand made upon it. It is therefore important that housing policies focus on developing a market-led housing finance system in the country. As shown in figure 1, it will ensure sustained flow of funds to prospective housing developers and the availability of long-term mortgages to individual home buyers.

\section{Housing Finance for Informal Sector and Low-Income Households}

Adequate provision of housing cannot be attained if the housing finance needs of the informal sector and low-income households are not catered for. The informal sector employs 47.8 percent of the currently employed population in the country (Ghana Statistical Service, 2008). The large size of the Ghanaian informal sector requires that the country's housing policy focuses on strategies that will address the housing needs of the households that rely on the informal sector for a living. But as Ferguson (1999) observes, the characteristics of the traditional mortgage market do not suit the circumstances of the low and middle-income households. Low-income earners may be ineligible for mortgage finance from the formal finance institutions (Kinyungu, 2004). The low and middleincome, and informal sector households are incapable of satisfying the underwriting requirements of lenders (Boamah, 2011). The banking institutions require that collateral be restricted to certifiable earnings of prospective borrowers (Karley, 2002). Boamah (2009) notes that the banks in Ghana require prospective mortgagors to be formally employed and have regular monthly income in order for lending to take place.

The income of the informal sector households fluctuate with the general fluctuations in the Ghanaian economy. Therefore, the low-income and the informal sector households may be excluded from the mortgage market by the lenders requirement. The informal sector and low income households may not be able to active ly participate in the country's mortgage market. Housing for the low income groups is rarely addressed by the private sector (developers and financiers). There is therefore the need for some form of State intervention to address the housing and housing finance needs of the low income households. It is important for Ghana to develop a housing finance scheme that will ensure the availability of housing funds to these categories of 
households. Figure 1 proposes the decoupling of informal sector housing finance from formal housing finance mechanisms.

Housing construction by the low-income households is executed gradually, according to the available sources of funds to owners (Karley, 2008). Low income families in urban areas in developing countries have irregular incomes; lack access to unambiguous land title; have modest income streams relative to their demand for food, education, housing, water, transport costs, health and emergencies (Klinkhamer, 2000). Insecurity of tenure and unstable income streams have compelled the low-income and informal sector households to build their homes tentatively, one wall at a time; houses are built informally and progressively (Malhotra, 2003). Low-income and informal sector households lack access to the formal finance markets and housing finance products that are tailored to the progressive building process used by them. But as Malhotra (2003) notes, the low-income people are reliable clients who are willing to pay the full cost for cost-effective financial services tailored to their needs.

The incremental building process is the major means through which housing is delivered in Ghana, therefore, the demand for housing finance services that suits the incremental building process is strong in the country. A Community Based Mutual Housing Finance Scheme (CBMHFS) would help in this regard (Karley, 2002; Boamah, 2011). It will enable households to pool their savings together to raise the necessary funds for housing investment. CBMHFS will enable its members to acquire adequate and affordable housing via the principles of self-help and regular savings. The mutual fund concept is part and parcel of the Ghanaian self-help spirit (Boamah, 2011). The "susu" schemes in Ghana are very popular, particularly to the informal sector workers and constitute an important and a massive savings mobilization schemes (Karley, 2002). Such schemes could be used to raise funds to finance housing for households who are unable to participate in the formal mortgage market. Housing finance down the market would be attained if the government and the CBMHFS work together; this would ensure the achievement of scale and the sustainability of the CBMHFS. CBMHFS can rely on social capital, household assets, or co-guarantors as effective collateral. The use of formal land title which disqualifies lowincome and informal sector households from the formal housing finance market would not be a prequisite for lending to take place.

Government has a key role to play in creating the enabling policy and regulatory environment for the development of CBMHFS in the country. Government policy must address issues such as capital adequacy, protection of depositors, usury laws, permitted level of intermediation, ownership structures of CBMHFS, and institutional soundness and sustainability. The regulatory environment must recognise that the low-income and informal sector households build their houses progressively. The regulatory environment must also appreciate that access to credit rather than the cost of credit is important to the low-income and informal sector households. Malhotra (2003) observes that the low-income households are voting with their feet and their message is loud and clear access to high-quality and efficient financial services are more important than cost. 
The regulatory framework must therefore not focus on the cost of housing funds at the expense of credit availability.

\section{Planning Controls}

The enactment and enforcement of development controls are extremely essential if Ghana is to solve its housing problem. Efficient planning control is essential in ensuring orderly and sustainable development, improved housing and neighborhood environment, the attainment of housing adequacy, the preservation of property values, and the enhancement of individual housing experience (Gough \& Yankson, 1997; Whitehead, 2007; Mohd, 2009; Boamah, Gyimah \& Nelson, 2012). Effective land use control will deal with increasing land use problems such as slum formation, incompatible land uses, flooding, overcrowding, congestion, environmental degradation and neighbourhood blight in most Ghanaian cities. This will ensure the sustainability of Ghanaian cities, cleaner and safe living environment, and the attainment of the health and safety needs of Ghanaians. Land-use regulations generate beneficial effects through the protection or enhancement of amenities that contribute to a community's health, safety, and welfare (Jaeger, 2006). Strict enforcement of land use regulations will ensure harmonious development of land, functional efficiency of housing and improved neighborhood characteristics. Figure 1 advocates the strengthening of the land use planning regime to facilitate housing development in the country.

The enforcement of land use regulations will make properties more acceptable as collateral for mortgage loans. Poor neighbourhood environment has ruled out several quality properties as adequate collateral for mortgages. The financial institutions require that the mortgaged property be located in a good neighbourhood before advancing housing loans (Ajanlekoko, 2001; Karley, 2002; Asare \& Whitehead, 2006; Boamah, 2009). Poorly planned neighborhoods constitute a disincentive to mortgagees and therefore undermine the development of the mortgage market. Enforcement of planning controls also enhances property values and hence the collateral value of properties. The creation of housing finance market greatly hinges on the nature and quality of the property to be mortgaged. This also depends on the characteristics of both the mortgaged property and the neighborhood. The quality housing environment that is required to facilitate the transfer of funds from lenders to home buyers cannot be achieved without enforcing planning rules and regulations. Housing policies in Ghana must therefore focus on ensuring strict compliance to development controls. This will make properties more attractive and acceptable to lenders as effective collateral.

Efforts should be made to avoid overregulation of the housing markets through planning controls. Also, the building and zoning standards must be realistic and reflect the country's state of development. The building permitting process must be less expensive and delays and its associated frustrations avoided. Overregulation and building standards that are inconsistent with the country's level of development will make formal housing 
unaffordable for the low-income households (Feiock, 2004; Quigley \& Raphael, 2004; Arnott, 2008; Mohd \& Abd Aziz., 2009). This would encourage the development of housing units that do not conform to planning regulations. It would thus reduce the ability of the planning authorities to influence the spatial development and the housing environment of Ghanaian cities. As Angel (2000) observes excessive and burdensome housing and land use regulation, and excessive fees will impede private housing development.

Despite the existence of adequate framework for land use regulations in the country, the planning authorities have shown limited interest or lack the capacity to enforce planning regulations within their jurisdictions. The public contempt for the planning system also appears to be high in the country. These are largely responsible for the disarticulated neighborhoods in Ghana. These issues have been exhaustively discussed by studies such as Konadu-Agyemang (2001), Boamah et al. (2012) and Baffour-Awuah and Hammond (2014).

\section{Public Private Partnerships}

Figure 1 points to the potential of Public Private Partnerships (PPP) to facilitate housing delivery in the country. The State via the Metropolitan-Municipal-District Assemblies (MMDAs) must explore opportunities for PPP for housing delivery in the country. The State through the MMDAs must partner with the private sector in the provision of housing. The MMDAs must focus on the provision of land whilst the private sector carries out the actual construction of the housing units and infrastructure delivery. That is, the State's equity in the PPP for housing ventures should be the provision of residential lots. The MMDAs can rely on the expropriation powers of the State to acquire land. This will ensure that land is readily released for housing development. The MMDAs equity concern should be the delivery of affordable housing but must also allow private firms to build houses of their own choice and to their own standards. The houses, however, must be consistent with the minimum acceptable housing standards set by legislation. The paper advocates for mixed development. This would ensure that affordable housing is delivered whilst allowing the private firms to maximize profits through innovative designs and the provision of housing varieties to meet the needs of both the upscale and downscale markets or the preferences of all consumers.

The critical role for the central government should be restricted to the creation of the necessary regulatory environment or framework, the regulation of the partnership ventures, support the MMDAs to compulsorily acquire land for such housing ventures, and also provide the necessary State backing to the MMDAs that conform to the PPP for housing (PPPH) guidelines. The backing and goodwill of the government are essential if the private sector is to be attracted to partner with the MMDAs in housing delivery. The government must regulate and not control the PPPH ventures. This would enable Ghana to take advantage of the financial strength and technical expertise of the private sector to develop housing to meet the housing needs of the population. To reap this benefit, 
requires that Ghana develops the broad legal and institutional framework for PPPH and interested MMDAs must develop strategic plans in line with the legal framework.

\section{Housing Research Fund}

Figure 1 proposes sustained housing research in the country. Research into housing finance, affordability, and livability; housing and neighborhood environment; development of quality and affordable building materials; changing population dynamics and consumer demand for housing; and improved building designs that would ensure energy efficiency and enhanced ventilation is required in the country. It is essential for policy makers to focus on housing research in the country. This should be supported by the specialised scientific institutions such as the Building and Road Research and the Forest Research Institutes in Kumasi; the Faculty of Planning and Land Economy and the Housing Research Centre of the Kwame Nkrumah University of Science and Technology; and the Faculty of Planning and Land Management of the University for Development Studies (U.D.S). These institutions which have been carrying out intensive research into housing have the capacity to provide appropriate, reliable and affordable technology to the housing sector and also serve as advisory bodies to government on matters of housing. This would ensure the availability of current and accurate research data to inform housing policy direction. Housing policy cannot be separated from housing research if it is to be successful. A national housing research fund should be established to finance continuous housing research in Ghana. There is the need to create structures that would link housing research to the housing industry and ensure industrial use of research findings.

\section{Conclusion}

Housing in Ghana is characterized by inadequate housing stock, poor conditions of the existing housing stock, haphazard development, lack of waste disposal facilities in most of the housing units, and inadequate financing mechanisms despite the formulation and implementation of several housing policies by post-independence governments of Ghana. Ghana must therefore create the appropriate environment necessary for the development of the housing sector and thus enable the sector to contribute meaningfully to the socio-economic development of the nation. This requires a clearly defined housing policy. The housing policy must create room for both the public and private sectors to contribute meaningfully to the development of the country's housing sector. It must also cater for the housing needs of both formal and informal sector workers and the low and high-income households. Policy makers must focus on creating the environment that will enable housing finance markets to work, design housing finance solutions that would satisfy the circumstances of low-income and informal sector households, ensure sustained housing research, develop and promote the use of local building materials, and explore the potentials of public private partnerships in housing delivery. Housing 
policy design should avoid expensive and broad-based housing programmes. The paper recommends that the feasible path for housing policy in Ghana is market-led housing finance systems; community-based housing finance schemes; planning controls; public private partnerships; establishment of housing research fund; and government regulation instead of control of the housing market. This would create the necessary platform for an accelerated development of the country's housing sector.

\section{References}

Abiodun, J. (1976). Housing Problems in Nigerian Cities, Town Planning Review, 47(4), pp. 339-47.

Ajanlekoko, J. S. (2001). Sustainable Housing Development in Nigeria: The Financial and infrastructural Implication-presented at the International Conference on Spatial Information for Sustainable Development held in Nairobi, Kenya, October, 2-5, 2001.

Adjei, P. O. W., \& P.O. Kyei (2013). Linkages between income, housing quality and disease occurrence in rural Ghana. Journal of Housing and the Built Environment, 1-15.

Akuffo, A. (2006). HFC'S Pioneering Role and Rational for Conversion to Full Banking Activities: Sustainability of Specialised Lenders. The World Bank/International Finance Corporation (IFC), Housing Finance Conference, 16-17 March, Washing DC, USA.

Angel, s. (2000). Housing Policy Matters. Oxford: Oxford University Press.

Arnott, R. (2008). Housing policy in developing countries: The importance of the informal economy. Urbanization and Growth, 167.

Asare, E. and C.M.E. Whitehead (2006). Formal mortgage markets in Ghana: nature and implications. RICS Research Paper Series, 6(13), 1-30.

Baffour Awuah, K. G., \& F. N. Hammond (2014). Determinants of low land use planning regulation compliance rate in Ghana. Habitat International, 41, 17-23.

Bank of Ghana (2007). The Housing Industry in Ghana: Prospects and Challenges, Bank of Ghana Policy Briefing Paper. Accra: BoG.

Boamah N.A. (2009). "Secondary Mortgage Market Market (SMM): Is it Right for Financing Housing in Ghana? Journal of Science and Technology, Vol.29, No. 1.

Boamah, N. A. (2011). Housing finance in Ghana: can community mortgage cooperatives provide a panacea? Ghana Journal of Development Studies, 7(1). 
Boamah, N. A. (2012). Housing for the Vulnerable in the Offinso South Municipality of Ghana, Housing, Care and Support, Vol. 15, No. 3, pp. 140-147.

Boamah, N. A., C. Gyimah and J.K.B. Nelson (2012). Challenges to the Enforcement of Development Controls in the Wa Municipality, Habitat International, Vol. 36, No. 1, pp. 136-142.

Bond, P., \& A. Tait (1997, March). The failure of housing policy in post-apartheid South Africa. Urban Forum, Vol. 8, No. 1, pp. 19-41. Springer Netherlands.

Buckley, R. M. (1996). Housing finance in developing countries. Basingstoke: Macmillan.

CHF International (2004). Strategic Assessment of the Affordable Housing Sector in Ghana, December, 2004.

CMHC [Canada Mortgage and Housing Corporation]. (2004a). Canadian Housing Observer, 2004. Ottawa: Canada Mortgage and Housing Corporation.

Conger, R. D., G. R. Patterson and X. Ge (1995). It takes two to replicate: A mediational model for the impact of parents' stress on adolescent adjustment. Child Development, 66(1), 80-97.

Corneil, T. A., L. M. Kuyper, J. Shoveller, R. S. Hogg, K. Li, P. M. Spittal, and E. Wood (2006). Unstable housing, associated risk behaviour, and increased risk for HIV infection among injection drug users. Health \& Place, 12(1), 79-85.

Dowall, D. E. (1989). Bangkok: A profile of an efficiently performing housing market. Urban $\underline{\text { Studies, } 26(3), 327-339 .}$

Early, D. W. (1998). The role of subsidized housing in reducing homelessness: An empirical investigation using micro囚data. Journal of Policy Analysis and Management, 17(4), 687-696.

Feiock, R. C. (2004). Politics, Institutions and Local Land-use Regulation, Urban Studies, 41:363.

Ferguson, B. (1999). Micro-finance of housing: a key to housing the low or moderateincome majority?. Environment and Urbanization, 11(1),

Ghana Statistical Service (2002). 2000 Population and Housing Census of Ghana. Accra: GSS.

Ghana Statistical Service (2008). Ghana Living Standards Survey, Report of the Fifth Round (GLSS 5). Accra: GSS.

Ghana Statistical Service (2013).2010 Population and Housing Census of Ghana, National Analytical Report. Accra: GSS. 
Gough, K.V. \& P.W.K. Yankson (1997). Continuity and Change: Socio-Economic and Environmental Consequences of Urban Growth in the Peri-urban Area of Accra.

Hettne, B. (1990). Development Theory and the Three Worlds. Harlow, Essex: Longman.

Hornsby-Odoi, E. and A. W. Glover-Akpey (1988). Providing for the Housing Needs of the people in the third world in Planning for Development in the Third World: Problems and Solutions (ed). Sam B. Amissah, Kumasi, Land Administration Research Centre.

Jaeger, W.K. (2006). The Effects of Land-Use Regulations on Property Values, Environmental Law, Vol.36: 105.

Jones, G. A \& P.M. Ward (1995)-The Blind Men and the Elephant: A Critic's Reply. International, 19(1), 61-72.

Karley, N. K. (2002 ). Alternative Options to Mortgages in Ghana, Housing Finance International, Vol. XVII /No.2: 26-30, December 2002.

Karley, N.K. (2008), Ghana Residential Property Delivery Constraints and Affordability Analysis, Housing Finance International, June, 2008.

Katz, L. F., J.R. Kling, \& J.B. Liebman (2001). Moving to opportunity in Boston: Early results of a randomized mobility experiment. The Quarterly Journal of Economics, 116(2), 607-654.

Kinyungu, A.N. (2004). Public-Private Sector Partnerships in the Servicing of Land and Provision of Housing for Low-income Groups in Harare: Experiences and Lessons Learnt 1990 - 1996, Our Common Estate, February 2004.

Klinkhamer, M. (2000). MicroFinance Housing Products and Experience with Land Title as Collateral. GHIF Report.

Kofie, R. Y. \& J.S. Nabila, J. S. (2004). "Poverty and Buruli Ulcer in Ghana Poverty, Health and Gender." Proceedings of the NUFU Workshop, pp. 44-45.

Konadu-Agyeman, K. (2001). The Political Economy of Housing and Urban Development in Africa: Ghana's Experience from Colonial Times to 1998. Praeger Publishers, Westport.

Krieger, J. and D. L. Higgins (2002). Housing and health: time again for public health action. Journal of Information, 92(5).

Mahama, C. and A. Antwi (2006). "Land and Property Markets in Ghana", Discussion Paper, Prepared by Royal Institution of Chattered Surveyors, World Urban Forum III, June 19-23, 2006. 
Malhotra, M. (2003). Financing her home, one wall at a time. Environment and Urbanization; 15; 217.

Mohd, I., F. Ahmad and W.N.W. Abd Aziz (2009). "Exploiting Town Planning Factors in Land Development: Case study of Urban Housing in Kuala Lumpur, Malaysia, Journal of Facilities Management, Vol. 7, No. 4, pp. 307-318.

Obeng-Odoom, F. \& L. Amedzro (2011). Inadequate Housing in Ghana, Urbani Izziv, Vol. 22, No. 1, pp. 127-137.

Ogu, V. I., \& J.E. Ogbuozobe (2001). Housing policy in Nigeria: towards enablement of private housing development. Habitat International, 25(4), 473-492.

Olsen, E. (2000). The cost-effectiveness of alternative methods of delivering housing subsidies. University of Virginia, Working Paper, (351).

Oppong, R. A. \& K.K. Adarkwa (2008). The paradox of landlessness - housing transformation and development at Abakam fishing village in Ghana, Journal of African Real Estate Research, Vol. 1, Issue 1, pp. 41-47.

Otiso, K. M. (2003). State, voluntary and private sector partnerships for slum upgrading and basic service delivery in Nairobi City, Kenya. Cities, 20(4), 221-229.

Parsons. W. (1995). Public Policy: An Introduction to the theory and practice of policy analysis. Edward Elgar, Aldershot.

Quigley, J. M., \& S. Raphael (2004). Is housing unaffordable? Why isn't it more affordable?. The Journal of Economic Perspectives, 18(1), 191-214.

Sanyal, B. (1996). Intention and outcome: formalization and its consequences. Regional Development Dialogue, 17, 161-178.

Sengupta, U. (2006). Government intervention and public-private partnerships in housing delivery in Kolkata. Habitat International, 30(3), 448-461.

Sinai, T. and J. Waldfogel (2002). Do Low-Income Housing Subsidies Increase Housing Consumption? (No. 8709). National Bureau of Economic Research.

Sinai, T., \& J. Waldfogel (2005). Do low-income housing subsidies increase the occupied housing stock?. Journal of Public Economics, 89(11), 2137-2164.

Strassmann, W. P. (1994). Oversimplification in housing analysis, with reference to land markets and mobility. Cities, 11(6), 377-383.

Surratt, H. L., \& J.A. Inciardi (2004). HIV risk, seropositivity and predictors of infection among homeless and non-homeless women sex workers in Miami, Florida, USA. AIDS care, 16(5), 594-604. 
Sandilands, R. J. (2002). How To Motivate Faster Growth in Colombia: The Leading Sector Strategy Revisited (Artículo publicado en inglés). Estudios Gerenciales, (85), 67-80.

Songsore, J. (2003). The Urban Housing Crisis in Ghana: Capital, the State versus the People, Ghana Journal of Social Science, Vol. 2, pp. 1-31.

Stren, R. (1990). "Housing Policy." In Housing Africa's Urban Poor. Amis, P. and Lloyed, P. (eds). Manchester, NY: Manchester University Press.

Thorns, D. C. (2006). The remaking of housing policy: the New Zealand housing strategy for the 21st century. Housing Finance International, 20(4), 20.

Tipple, A. G. (1987). The Development of Housing Policy in Kumasi, Ghana 1901-1981. Newcastle Upon Tyne: Center for Architectural Research and Development Overseas.

Vakil, A. C. (1999). Problems and prospects of housing CBOs: An analysis of 30 case studies from Africa and Latin America, 1964-1994. Cities, 16(6), 409-422.

Whitehead, C. M. E. (2007). Planning Policies and Affordable Housing: England as a Successful Case Study? Housing Studies, Vol. 22, No. 1, pp. 25-44. 